\title{
Severe ocular and risk organ involvement in a newborn with Langerhans Cell Histiocytosis
}

\author{
Alice Brambilla ${ }^{1}$, Francesco Pegoraro ${ }^{1}$, Maria Luisa Coniglio ${ }^{1}$, Roberto Caputo $^{1}$, Anna \\ Perrone $^{1}$, Anna Maria Buccoliero ${ }^{1}$, Claudio Favre ${ }^{1}$, and Elena Sieni ${ }^{1}$ \\ ${ }^{1}$ Azienda Ospedaliero Universitaria Ospedale Pediatrico Meyer
}

May 20, 2020

\begin{abstract}
Langerhans Cell Histiocytosis $(\mathrm{LCH})$ is a rare proliferative disease of the mononuclear phagocyte system, characterised by tissue infiltration of CD1a+ CD207+ histiocytes. The clinical presentation is variable, ranging from unifocal asymptomatic bone involvement to life-threatening multisystem disease, requiring aggressive therapeutic approaches. Intraocular involvement is uncommon and associated to poor visual and general prognosis. Herein, we report a case of LCH in a newborn with ocular and multisystem risk organ involvement, unresponsive to several lines of chemotherapy. Off-label administration of vemurafenib led to dramatic improvement at systemic level; however, chronic sequelae of ocular involvement resulted in poor visual prognosis.
\end{abstract}

\section{Hosted file}

Manuscript.doc available at https://authorea.com/users/324400/articles/452601-severe-ocularand-risk-organ-involvement-in-a-newborn-with-langerhans-cell-histiocytosis

Hosted file

Table 1.docx available at https://authorea.com/users/324400/articles/452601-severe-ocularand-risk-organ-involvement-in-a-newborn-with-langerhans-cell-histiocytosis 

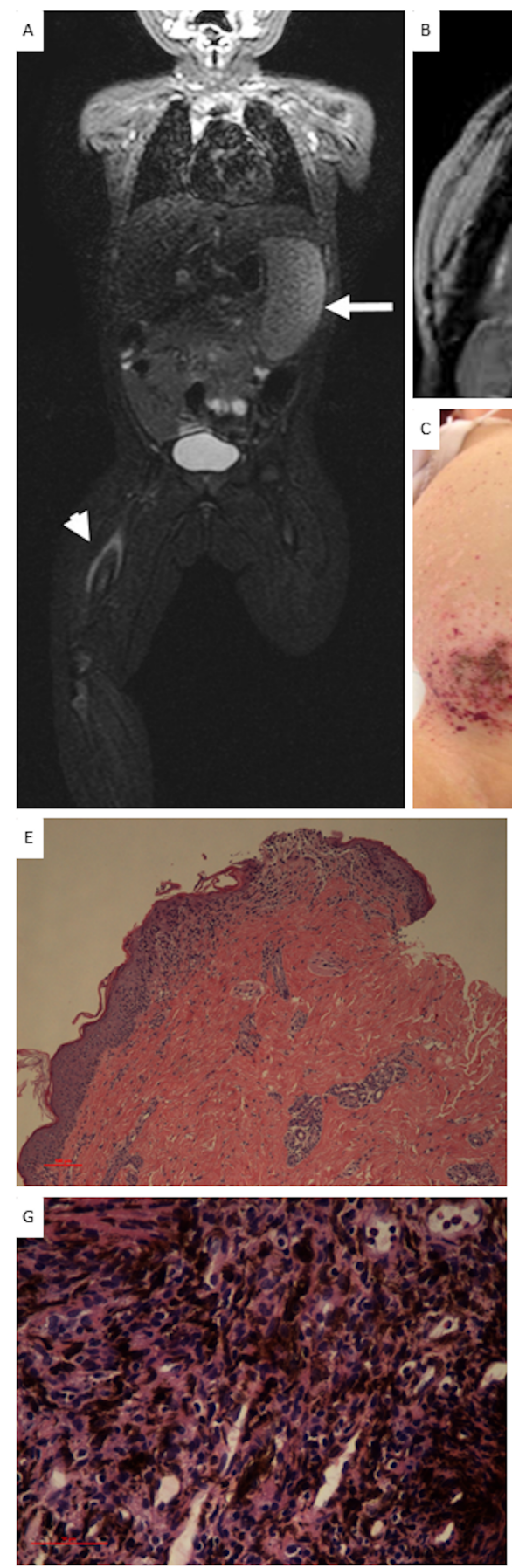
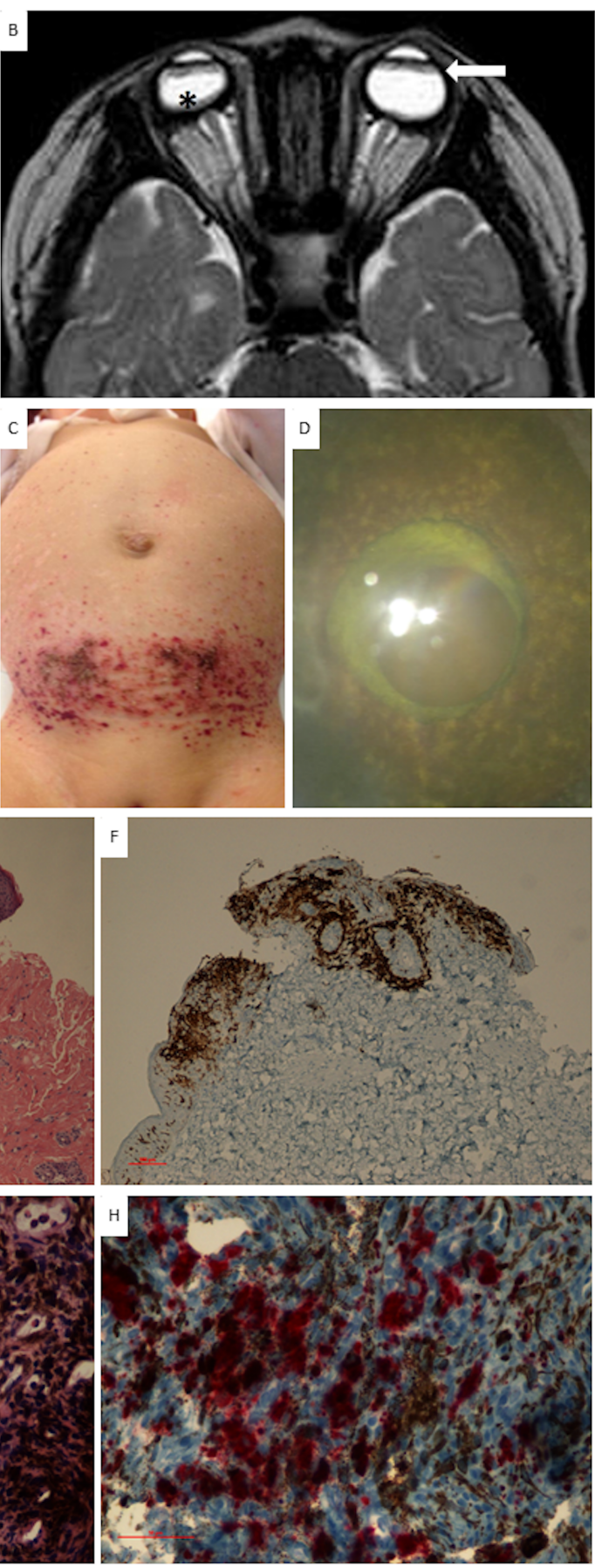